\title{
Chemical composition and cytotoxic activity of the essential oil from the aerial parts of Dorema aucheri
}

\author{
Seyed Ahmad Hossiniyan ${ }^{\mathbb{D}}$, Farideh Ghalamfarsa ${ }^{\circledR}$, Shaghayegh Rostami-Yasuj ${ }^{\mathbb{D}}$, Zeynab Salehpoor $^{(\mathbb{1}}$, \\ Mohsen Latifpour $^{1}{ }^{\mathbb{D}}$, Sajad Hasanzadeh $^{2}{ }^{\mathbb{D}}$, Bahram Mohammadi $^{\mathbb{D}}$, Farhad Jadidi-Niaragh $^{3,4,5}$, Ali Ganji $^{6,7}$, \\ Ghasem Ghalamfarsa ${ }^{1^{*} \mathbb{D}}$ \\ ${ }^{1}$ Medicinal Plants Research Center, Yasuj University of Medical Sciences, Yasuj, Iran \\ ${ }^{2}$ Department of Internal Medicine, Yasouj University of Medical Sciences, Yasouj, Iran \\ ${ }^{3}$ Immunology Research Center, Tabriz University of Medical Sciences, Tabriz, Iran \\ ${ }^{4}$ Department of Immunology, Faculty of Medicine, Tabriz University of Medical Sciences, Tabriz, Iran \\ ${ }^{5}$ Department of Immunology, Faculty of Medicine, Tehran University of Medical Sciences, Tehran, Iran \\ ${ }^{6}$ Molecular and Medicine Research Center, Arak University of Medical Sciences, Arak, Iran \\ ${ }^{7}$ Department of Microbiology and Immunology, School of Medicine, Arak University of Medical Sciences, Arak, Iran
}

\section{A R T I C L E I N F O}

Article Type:

Original Article

\section{Article History:}

Received: 3 March 2021

Accepted: 25 May 2021

\section{Keywords:}

Apoptosis

Colorectal cancer

Dorema aucheri

Essential Oil

\begin{abstract}
A B S T R A C T
Introduction: Herbal products are beneficial compounds with many applications in human life. In this study the chemical composition and cytotoxic activity of the essential oil of the aerial parts of Dorema aucheri were assessed.

Methods: The essential oil was extracted by hydrodistillation after drying the aerial parts of $D$. aucheri, collected from the mountains around Yasuj city in the South-West of Iran. The oil composition was determined by GC/MS. To evaluate in vitro cytotoxic activity, the apoptotic effects of the essential oil were investigated against SW48 and SW1116 colorectal cancer cell lines by (3-[4, 5-dimethylthiazol-2-yl]-2, 5 diphenyl tetrazolium) bromide (MTT) assay and flow cytometry.

Results: The essential oil yield was obtained $0.02 \%(\mathrm{~W} / \mathrm{W})$. Twenty-five compounds were identified in the oil, and the main constituents were caryophyllene (E) (31.29\%), Phytol (14.92\%), gurjunene $(\beta-)$ (9.84\%), 3,7,11,15-tetramethyl-2-hexadecen-1-ol (8.7\%), and $n$-hexadecanoic acid $(8.09 \%)$. The MTT assay showed that the $\mathrm{IC}_{50}$ values of the essential oil for SW48 and SW 1116 cell lines were 1.4 and $1.2 \mathrm{mg} / \mathrm{mL}$, respectively. The results of flow cytometry showed that the essential oil significantly increased the apoptosis in SW48 cell line compared with the vincristine $(P<0.05)$. It also increased the apoptosis in SW1116 cells compared with the vincristine, but this difference is not significant.

Conclusion: The essential oil of D. aucheri consisted of high amounts of caryophyllene and showed significant cytotoxic effects against SW48 and SW1116 cancerous cell lines.
\end{abstract}

Implication for health policy/practice/research/medical education:

The essential oil of $D$. Aucheri comprised of high amounts of caryophyllene and showed significant cytotoxic effects against SW48 and SW1116 cancerous cell lines. Hence, after more comprehensive studies, it might be used as a beneficial herbal source for developing anti-tumor drugs.

Please cite this paper as: Hossiniyan SA, Ghalamfarsa F, Rostami-Yasuj S, Salehpoor Z, Latifpour M, Hasanzadeh S, et al. Chemical composition and cytotoxic activity of the essential oil from the aerial parts of Dorema aucheri. J Herbmed Pharmacol. 2021;10(3):344-350. doi: 10.34172/jhp.2021.40.

\section{Introduction}

Dorema aucheri is a plant of Apiaceae family which grows at the end of the spring in southern provinces of Iran, especially in the provinces bordering the margins of the Zagros mountains, such as Kohgiluyeh and BoyerAhmad (1,2). The plant has medicinal properties and also is used by the local inhabitants for preparing food $(1,3-5)$. It has already been proven that the aerial parts of the $D$. aucheri are rich in flavonoids (6). Flavonoids represent a large group of polyphenolic compounds that exhibit anti-oxidative effects $(7,8)$. Although several reports have been conducted on the phytochemistry and 
bioactivity of hydroalcoholic extract of $D$. aucheri, the compounds and bioactivity effects of its essential oil have not been clearly determined. Several studies have reported hepatoprotective, anti-diabetic, anti-tumor, anti-oxidant, anti-hyperlipidemic, and anti-hypercholesterolemic effects of the hydroalcoholic extract of this plant (1,3-5,9). Moreover, in several pathophysiological states, it has been reported that $D$. aucheri extract has positive effects on thyroid hormones, antioxidant enzymes, the haematologic system and also serum levels of testosterone, folliclestimulating hormone (FSH) and luteinizing hormone (LH) (10). The analysis of essential oil extracted from the leaves of $D$. aucheri showed that it contained 36 (99.86\%) compounds, and the major constituents included curzerene (18.7\%), a-eudesmol (7.72\%), Spathulenol (6.68\%), isohibaene (6.16\%), and gemberen (6.66\%) (11). In several studies concerning the extracts of the aerial parts of $D$. aucheri, the presence of a large group of terpenoids, more specifically the sesquiterpene compounds, have been demonstrated. It has been indicated that the pharmacological features of $D$. aucheri, and its potential role in anti-inflammatory, and in the treatment of thyroid disorders and tumors can be due to its sesquiterpene compounds (12). In the present study, the constituents and bioactivity of the essential oil of $D$. aucheri were determined by GC-MS analysis. Also, the cytotoxic effects of these compounds were evaluated against two colorectal cancer cell lines (SW48 and SW1116).

\section{Materials and Methods}

Plant materials

The aerial parts of $D$. aucheri were collected from the mountains near the Yasuj city $(25 \mathrm{~km}$ away from the city, at $30.4658640 \mathrm{~N}, 51.6783400 \mathrm{E}$, and the altitude of 2430 $\mathrm{m}$ ) in Kohgiluyeh and Boyer-Ahmad province, Iran, in the spring of 2017. The plant was authenticated by a botanist (Dr. Azizollah Jafari, a botanist at Yasuj University, faculty of science). The aerial parts were dried in a dark place and then were powdered by an electric grinder. The voucher specimen of the authenticated plant (voucher no. 0496) was deposited at the herbarium of Medicinal Plants Research Center, Yasuj University of Medical Sciences.

\section{Preparation of essential oil}

The powder of $D$. aucheri (1200 g) was hydro-distilled in several runs for 4 hours using a Clevenger apparatus. The essential oil was collected, dried with anhydrous sodium sulfate, and kept in refrigerator until GC-MS analysis.

GC-MS analysis and identification of the oil components The GC-MS analysis of the oil was conducted using a Hewlett-Packard 6890 instrument equipped with a HP$5 \mathrm{M}$ capillary column (phenyl methyl siloxane, $25 \mathrm{~m} \times 0.25$ mm id, Hewlett-Packard Part No. 190915.433, USA). The oven temperature was adjusted from $50^{\circ} \mathrm{C}$ ( 3 minutes) to $250^{\circ} \mathrm{C}$ at the speed of $3^{\circ} \mathrm{C} \mathrm{min}-1$ and finally continued for 10 minutes at $250^{\circ} \mathrm{C}$. The injection temperature was $250^{\circ} \mathrm{C}$. Helium was used as the transferor gas at a constant flow rate of $1.2 \mathrm{~mL} / \mathrm{min}$. The mass spectrometer (HewlettPackard 5973, USA) was activated in the electron ionization (EI) mode at $70 \mathrm{Ev}$ and the mass range was 30$600 \mathrm{~m} / \mathrm{z}$. The identification of components was performed by comparing the relative retention times with those of a series of $n$-alkane standards (C10 to C30: ref. no. R-8769, Sigma) and linear interpolation based on computer matching with the Willey library (Willey-275) and spectra literature data (13).

\section{Cell lines and culturing}

Human colorectal cancer cell lines (SW48 and SW1116) were obtained from the Pasteur Institute of Iran. The cell lines were cultured in RPMI-1640 supplemented with 10\% fetal calf serum, $1 \%$ glutamine, and $100 \mathrm{U} / \mathrm{mL}$ penicillin/ streptomycin. The cells were cultured in a humidified atmosphere at $37^{\circ} \mathrm{C}$ and $5 \% \mathrm{CO}_{2}$.

\section{Cell proliferation assay}

The cellular proliferation was assessed using MTT (3[4, 5-dimethylthiazol-2-yl]-2, 5 diphenyl tetrazolium bromide) assay. The cells $\left(5 \times 10^{4}\right)$ were seeded in each well of a microplate, containing $100 \mu \mathrm{L}$ of the RPMI medium supplemented with $10 \%$ FBS. After a 24 hours incubation, the cells were attached to the bottom of each well, and treated with $D$. aucheri essential oil at the concentrations of 0.2 to $1.6 \mathrm{mg} / \mathrm{mL}$ for 24 hours. Then, $5 \mathrm{mg} / \mathrm{mL}$ MTT reagent was added to each well, and the plate was incubated at $37^{\circ} \mathrm{C}$ for 4 hours. As the positive control, the cells were treated with vincristine (Sobhan Oncology Co., Iran). Next, the supernatant was removed, and $100 \mu \mathrm{L}$ DMSO was added to each well. Finally, the optical density of wells was determined at $490 \mathrm{~nm}$ using a microplate reader (Stat Fax3200, Awareness Technology, USA).

\section{Apoptosis assay}

The SW48 and SW 1116 cells $\left(1 \times 10^{6}\right.$ cells per well $)$ were seeded in six-well plates and then treated with either medium alone (negative control), D. aucheri essential oil $(1.4$ and $1.2 \mathrm{mg} / \mathrm{mL})$, or vincristine $(0.05$ and $0.04 \mathrm{mg} /$ $\mathrm{mL})$ for 24 hours. The cells were resuspended in a cold binding buffer, then stained with annexin V-FITC reagent $(5 \mu \mathrm{L})$ and propidium iodide $(\mathrm{PI})(5 \mu \mathrm{L})$, and incubated in the dark at room temperature for 15 minutes. After adding $500 \mu \mathrm{L}$ of the binding buffer, fluorescence was read using a fluorescence-activated cell sorter (FACS) (BD Biosciences, San Diego, CA, USA). Flow cytometry data was analyzed by FlowJo software. All the samples were assayed in triplicate.

\section{Statistical analysis}

For statistical analysis, the data of cytotoxic activity was compared between different groups by the analysis of 
variance (ANOVA) followed by Tukey's post hoc test. The probability value of $P<0.05$ was considered to denote a statistically significant difference.

\section{Results}

The yield of the essential oil extraction was $0.02 \%$ (W/W). GC-MS chromatogram of essential oil from the aerial parts of Dorema aucheri is shown in Figure 1. The results of GC-MS analysis (Table 1) showed that there were twenty-five (98.39\%) known compounds in this essential oil. The main constituents included caryophyllene $(E)$ (31.29\%), phytol (14.92\%), gurjunene $(\beta-)(9.84 \%)$, 3,7,11,15-tetramethyl-2-hexadecen-1-ol (8.70\%), and $n$-hexadecanoic acid (8.09\%).

\section{Cytotoxic activity}

MTT assay was used to determine the $\mathrm{IC}_{50}$ of D. aucheri essential oil on SW48 and SW1116 cell lines. The cells were treated with 0.2 to $1.6 \mathrm{mg} / \mathrm{mL}$ concentrations of D. aucheri essential oil (Table 2). In parallel, vincristine was used as a positive control. The result showed that the essential oil significantly $(P<0.05)$ inhibited the cell growth of SW48 and SW1116 cell lines. As shown in Table 3, the $\mathrm{IC}_{50}$ values (The inhibitory concentrations that could reduce 50\% of SW48 and SW 1116 cells) were 1.4 and $1.2 \mathrm{mg} / \mathrm{mL}$ for essential oil and 0.05 and $0.04 \mathrm{mg} /$ $\mathrm{mL}$ for vincristine, respectively. The results showed that the SW1116 cell line was more sensitive than SW48 to D. aucheri essential oil. Also, it was shown that the SW48 cell line was more resistant than SW1116 to vincristine.

\section{Apoptosis}

To explore the mechanism by which $D$. aucheri essential oil might exert its anti-proliferative effects on SW48 and SW1116 cell lines, we assessed apoptosis using Annexin $\mathrm{V}$ and PI assay. The respective dot plots of this analysis have been shown in Figure 2. Based on the $\mathrm{IC}_{50}$ values, the cells were exposed to the essential oil for 24 hours to stimulate apoptosis. Flow cytometry results indicated that, 24 hours incubation with the essential oil significantly elevated apoptosis in SW48 cell line, compared with the vincristine $(P<0.05)$. It also increased the rate of
Table 1. List of the components of the essential oil of Dorema aucheri

\begin{tabular}{|c|c|c|}
\hline Compound & Essential oil\% & Kovats indices (K.I) \\
\hline Linalool & 0.37 & 1084 \\
\hline Ylangene & 0.49 & 1367 \\
\hline Caryophyllene (E) & 31.29 & 1413 \\
\hline Aromadendrene & 0.94 & 1420 \\
\hline Gurjunene ( $\beta-)$ & 9.84 & 1426 \\
\hline Barbatene ( $\beta-)$ & 0.69 & 1432 \\
\hline Humulene ( $\alpha-)$ & 1.30 & 1445 \\
\hline Acoradiene $(\alpha-)$ & 0.34 & 1458 \\
\hline Curcumene ( $\alpha-)$ & 1.78 & 1468 \\
\hline Selinene $(\beta-)$ & 1.01 & 1477 \\
\hline Selinene $(\alpha-)$ & 0.74 & 1487 \\
\hline Cuparene & 3.28 & 1490 \\
\hline Curcumene ( $\beta-)$ & 0.47 & 1500 \\
\hline Bazzanene $(\beta)$ & 0.64 & 1509 \\
\hline Nerolidol ( $E-)$ & 0.57 & 1534 \\
\hline Longipinanol & 0.99 & 1555 \\
\hline Caryophyllene oxide & 2.55 & 1562 \\
\hline Globulol & 0.37 & 1566 \\
\hline Tridecanol (n-) & 2.82 & 1576 \\
\hline Unknown & 0.94 & 1622 \\
\hline $\begin{array}{l}\text { 1,2-Benzenedicarboxylic } \\
\text { acid, bis(2-methylpropyl) } \\
\text { ester }\end{array}$ & 2.85 & 1822 \\
\hline Cyclopentadecanolide & 0.55 & 1826 \\
\hline $\begin{array}{l}\text { 3,7,11,15-Tetramethyl-2- } \\
\text { hexadecen-1-ol }\end{array}$ & 8.70 & 1836 \\
\hline Unknown & 0.53 & 1877 \\
\hline Ethyl Linoleolate & 2.80 & 1909 \\
\hline$n$-Hexadecanoic acid & 8.09 & 1943 \\
\hline Phytol & 14.92 & 2092 \\
\hline
\end{tabular}

apoptosis in SW 1116 cells compared with the vincristine, but this difference was not significant (Figure 3). The apoptosis rates in SW48 and SW1116 cell lines treated with $D$. aucheri essential oil were $14.93 \%$ and $7.1 \%$, while the cells treated with vincristine showed $4.5 \%$ and $6.43 \%$ apoptosis rates, respectively. Also, the essential oil treatment significantly elevated apoptosis in SW48 and SW1116 cell lines, compared with the negative control ( $P$ $<0.05)$. The comparison of apoptosis rates between SW48 and SW1116 cell lines showed that D. aucheri essential oil induced a significantly higher apoptosis rate in the SW48

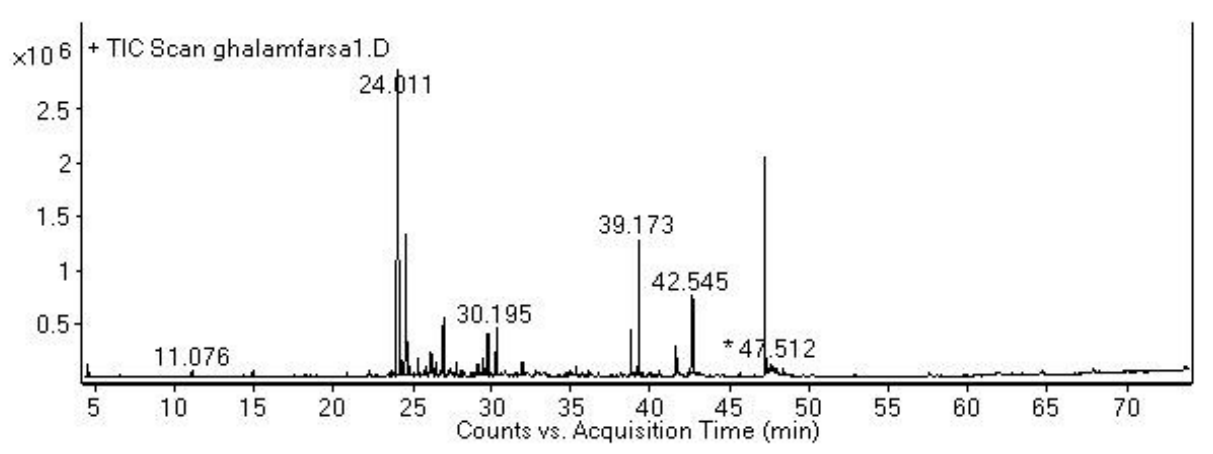

Figure 1. GC-MS chromatogram of essential oil from the aerial parts of Dorema aucheri. 
Table 2. Effect of different concentrations of essential oil of $D$. aucheri aerial parts on viability of SW48 and SW1116 cells after 24 hours using MTT assay

\begin{tabular}{lc}
\hline \multirow{2}{*}{ Concentration $(\mathrm{mg} / \mathrm{mL})$} & Cell viability (\%) \\
\cline { 2 - 2 } 0.2 & SW48 SW1116 \\
0.4 & 92.4291 .23 \\
0.6 & 90.5489 .71 \\
0.8 & 88.3885 .42 \\
1 & 75.3667 .31 \\
1.2 & 68.3960 .03 \\
1.4 & 57.4350 .44 \\
1.6 & 49.2747 .12 \\
\hline
\end{tabular}

SW48: Human colorectal cancer cell line, SW1116: Human colorectal cancer cell line.

Table 3. Cytotoxic activity of essential oil from the aerial parts of $D$. aucheri

\begin{tabular}{lll}
\hline \multirow{2}{*}{ Sample } & \multicolumn{2}{l}{ MTT assay, IC50 $(\mathrm{mg} / \mathrm{mL})$} \\
\cline { 2 - 3 } & SW48 & SW1116 \\
\hline Essential oil & $1.4 \pm 0.05$ & $1.2 \pm 0.02$ \\
Vincristine & $0.05 \pm 0.001$ & $0.04 \pm 0.001$ \\
\hline
\end{tabular}

IC50: The half maximal inhibitory concentration, SW48: Human colorectal cancer cell line, SW1116: Human colorectal cancer cell line, MTT: microculture tetrazolium.

Results are expressed as means \pm SD of three independent MTT assay performed in triplicate. Vincristine was tested as positive control.

cell line $(P<0.05)$.

\section{Discussion}

The current treatments for cancer, such as chemotherapy and radiotherapy, despite having cytotoxic effects against cancer cells, are associated with the side effects on normal proliferating cells. Therefore, it is required to develop alternative therapeutic approaches with the least possible complications (14-16). Among the potential sources for novel therapeutics, medicinal plants can be the most important options due to their anticancer components such as phenolics, glycosides, steroids, flavonoids, and terpenoids (17-19).

Although several studies have been carried out regarding the beneficial health effects of hydroalcoholic extract of the $D$. aucheri $(3,4)$, there is inadequate knowledge about the composition and properties of the essential oil of this plant. In this study GC-MS analysis showed that terpenoids constituted $70.88 \%$ of the compounds identified in the investigated oil, among which sesquiterpenes (55.59\%), diterpenes (14.29\%), and monoterpenes $(0.37 \%)$ were the predominant terpene compositions. Despite differences in the types of compounds, these compositions demonstrated similar biological functions compared to those of other plant species assessed in prior studies $(7,8,20)$. Asnaashari et al who analyzed the composition of the essential oil of $D$. glabrum roots by GC/MS method showed that the oil was rich in sesquiterpenes and monoterpenes (21). In another study, the major constituents of the essential oil of $D$. ammoniacum collected from the Kellar mountain, were three hydrocarbon monoterpenes, five oxygenated monoterpenes, ten sesquiterpene hydrocarbons, and thirteen oxygenated sesquiterpenes (22). Akbarian et al in their study, conducted on five $D$. aucheri populations in different regions of Iran, showed that $\beta$-caryophyllene, thymol, $\beta$-gurjunene, carvacrol, and cuparene were the major components (23). In contrast, in the study of Delnavazi et al on D. glabrum plant, although the main components were non-terpene compounds (56\%), terpenes were also widely found in the plant (24).

In our study, the analysis of essential oil of $D$. aucheri

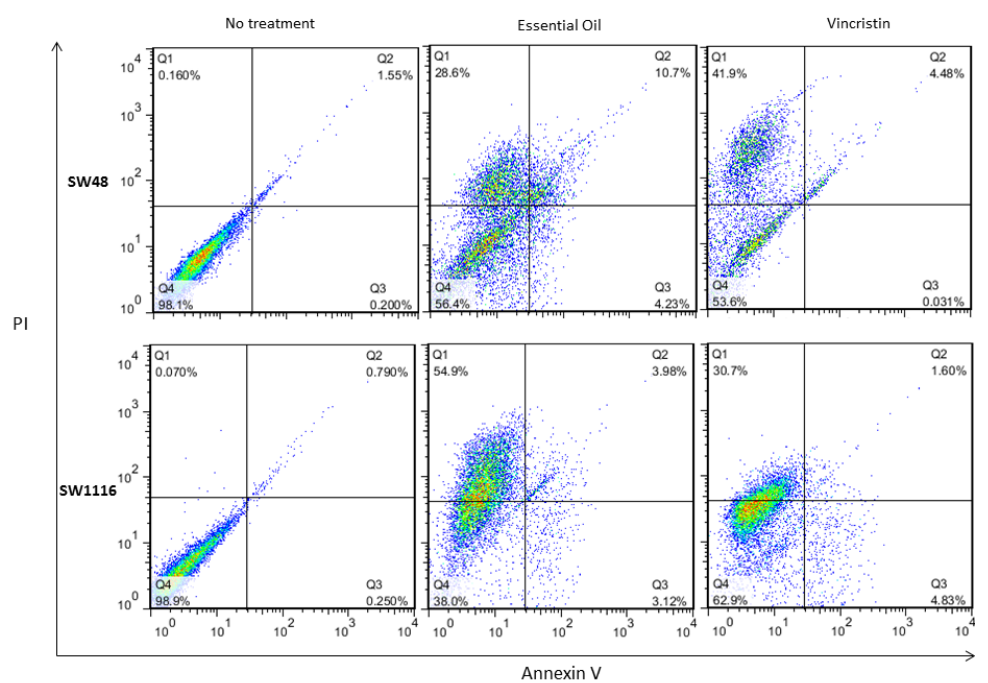

Figure 2. Flow cytometry results showing the percentage of apoptotic (early and late apoptosis), live, and necrotic cells following the treatment of SW48 and SW1116 cell lines with $D$. aucheri essential oil and vincristine. The treated cells with the essential oil and vincristine have shown significant increase $(P$ $<0.05$ ) in the proportion of cells entering necrosis stage. Also, compared to vincristine, the essential oil significantly elevated apoptosis in SW48 cell line. NT: no treatment, PI: Propidium iodide. Q1: necrosis, Q2: late apoptosis, Q3: early apoptosis, Q4: alive. 


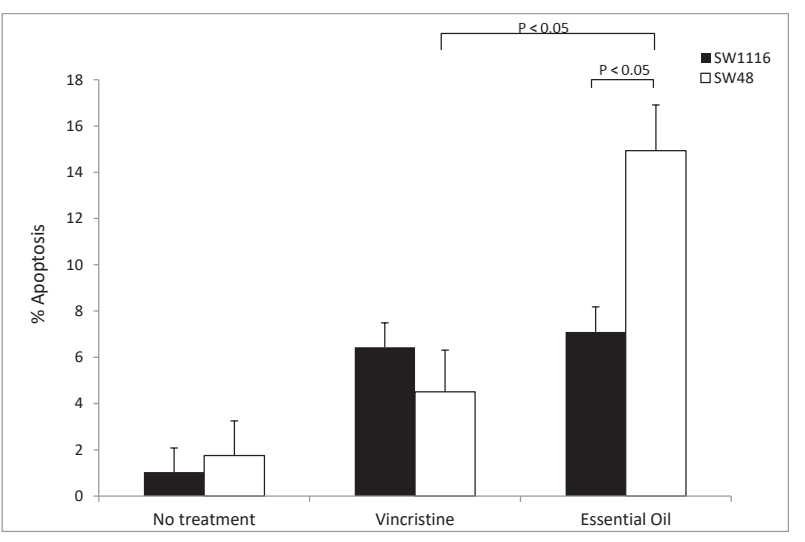

Figure 3. The apoptotic effects of the essential oil of $D$. aucheri on SW48 and SW1116 cell lines. The data represent mean \pm SEM.

showed that a-eudesmol was absent, while this compound has been identified in other species of Dorema. In the analysis of the oil extracted from $D$. aucheri collected from the Hezar mountain, the main components were a-eudesmol (31.2\%) and $\delta$-cadinene (10.9\%) (25). Also, the chemical composition of the essential oil from the stems and seeds of Dorema ammoniacum revealed a remarkable difference with our study (26). The reason for the discrepancy between our findings and previous ones can be due to the different environmental conditions leading to qualitative and quantitative variations in the compositions of oils (27).

Because terpenoids have been found to suppress the growth of a variety of cancer cells, the aim of the present study was to evaluate the biological effects of the essential oil of D. aucheri on SW48 and SW1116 colorectal cancer cell lines (28). The MTT assay was performed to evaluate in vitro cytotoxic activity of the essential oil against the cancer cell lines. The results showed that the essential oil of D. aucheri inhibited the growth of these cells as compared to vincristine. Our results also showed that the oil extract had greater toxic effects against the SW 1116 cell line with the $\mathrm{IC}_{50}$ of $1.2 \mathrm{mg} / \mathrm{mL}$ compared to the value of $1.4 \mathrm{mg} / \mathrm{mL}$ obtained for the SW48 cell line.

We also evaluated the apoptotic effects of essential oil of D. aucheri against the mentioned cell lines using Annexin $\mathrm{V}$ and PI assay. The flow cytometry results indicated that 24 hours incubation with the extract significantly elevated apoptosis in SW48 cell line, compared to vincristine. The essential oils of D. glabrum and D. ammoniacum have been shown to effectively induce apoptosis in cancerous cell lines (29,30). Many studies have also demonstrated that the essential oil constituents of plants such as terpenoids present anti-cancer and pro-apoptotic effects and inhibit the differentiation, angiogenesis, invasion, and metastasis of tumor cells $(28,31,32)$. In the present study, caryophyllene, a type of sesquiterpene, comprised the major compound (31.29\%) of essential oil of D. aucheri. Several studies have shown the anti-cancer effects of this compound on osteosarcoma and breast tumors (3335). Phytol, as a diterpene with anticancer effects (36), was the second major compound of $D$. aucheri essential oil with a concentration of $14.92 \%$. This compound can be considered a possible candidate for a wide range of applications in pharmaceutical, food, and biotechnological industries (37).

\section{Conclusion}

The essential oil of $D$. Aucheri comprised of high amounts of caryophyllene and showed significant cytotoxic effects against SW48 and SW1116 cancerous cell lines. Hence, after more comprehensive studies, it can be used as a beneficial herbal source for developing anti-tumor drugs.

\section{Acknowledgment}

We would like to thank our colleagues in Zardband company, which is an herbal medicine company. More specifically, we thank Mr. Taqizadeh and Mr. Ansari, who helped us in the extraction process of the essential oil from the $D$. aucheri.

\section{Authors' contribution}

$\mathrm{SAH}, \mathrm{GGH}, \mathrm{FJN}, \mathrm{AG}, \mathrm{SH}$ and $\mathrm{BM}$ contributed in designing the study, supervising, editing the manuscript and analyzing the data. GGH, FGH, SRY participated in the writing process. SAH, FGH, ZS and ML performed experiments. The final manuscript was read and approved by all authors.

\section{Conflict of interests}

The authors have no conflict of interests to declare.

\section{Ethical considerations}

This study was approved by the Ethical Committee of Yasuj University of Medical Sciences, Yasuj, Iran (ir.yums. rec.1395.213). Ethical issues (including text plagiarism, data fabrication and redundant publication) have been carefully observed by the authors.

\section{Funding/Support}

This work was financially supported by Research Department of Yasuj University of Medical Sciences, Yasuj, Iran (Grant No. 740).

\section{References}

1. Afshoon E, Ostad Rahimi A, Sadeghi H, Afshoon T, Mahdavi R. The effect of Dorema aucheri extract on breast tumor induced by DBMA in rats. Armaghane Danesh. 2010;15(3):224-32. [Persian].

2. Mianabadi M, Hoshani M, Salmanian S. Antimicrobial and anti-oxidative effects of methanolic extract of Dorema aucheri Boiss. J Agric Sci Technol. 2015;17(3):623-34. [Persian].

3. Azarnioushan F, Khatamsaz S, Sadeghi HE. The effects of hydro alcoholic extract of Dorema aucheri on blood concentration of gonadotropin and androgen hormones 
in adult male rats. Armaghane Danesh. 2009;14(3):63-70. [Persian].

4. Ahangarpour A, Teymuri Zamaneh H, Jabari A, Malekshahi Nia $H$, Heidari $H$. Antidiabetic and hypolipidemic effects of Dorema aucheri hydroalcoholic leave extract in streptozotocin-nicotinamide induced type 2 diabetes in male rats. Iran J Basic Med Sci. 2014;17(10):808-14.

5. Mostafavi SH, Fazilati M, Mostafavi SA, Vahhabi MR, Mostafavi F, Omidvarinia S, et al. Hepatotoxicity of Dorema aucheri (Bilhar) in albino mice. Arch Iran Med. 2013;16(9):530-2.

6. Wollenweber E, Dörr M, Rustiyan A. Dorema aucheri, the first umbelliferous plant found to produce exudate flavonoids. Phytochemistry. 1995;38(6):1417. doi: 10.1016/0031-9422(94)00840-p.

7. Tavakoli J, Miar S, Zadehzare MM, Akbari H. Evaluation of effectiveness of herbal medication in cancer care: a review study. Iran J Cancer Prev. 2012;5(3):144-56.

8. Safarzadeh E, Sandoghchian Shotorbani S, Baradaran B. Herbal medicine as inducers of apoptosis in cancer treatment. Adv Pharm Bull. 2014;4(Suppl 1):421-7. doi: 10.5681/apb.2014.062.

9. Neoushan Fa, Karami M, Gholizadeh L, Davari K. The effect of Dorema aucheri-hydroalcoholic extracts on thyroids hormones in adult male rats. J Shahrekord Univ Med Sci. 2010;12(2):84-8. [Persian].

10. Rasouli Vani J, Taghi Mohammadi M, Sarami Foroshani M, Rezazade E. Evaluation of the neuroprotective and antioxidant effects of Dorema aucheri extract on cerebral ischaemia-reperfusion injury in rats. Pharm Biol. 2019;57(1):255-62. doi: 10.1080/13880209.2019.1597132.

11. Khanahmadi M, Miraghaee SS, Karimi I. Evaluation of the antioxidant and antimicrobial properties of Dorema aucheri plant. Iran Red Crescent Med J. 2012;14(10):684-5.

12. Nahvinejad M, Pourrajab F, Hekmatimoghaddam S. Extract of Dorema aucheri induces PPAR- $\gamma$ for activating reactive oxygen species metabolism. J Herb Med. 2016;6(4):171-9. doi: 10.1016/j.hermed.2016.09.003.

13. Ghasemi Y, Abedtash H, Morowvat MH, Mohagheghzadeh A, Ardeshir-Rouhani-Fard S. Essential oil composition and bioinformatic analysis of Spanish broom (Spartium junceum L.). Trends Pharm Sci. 2015;1(2):97-104.

14. Abbasi BA, Iqbal J, Ahmad R, Bibi S, Mahmood T, Kanwal $\mathrm{S}$, et al. Potential phytochemicals in the prevention and treatment of esophagus cancer: a green therapeutic approach. Pharmacol Rep. 2019;71(4):644-52. doi: 10.1016/j.pharep.2019.03.001

15. Kawabe T. G2 checkpoint abrogators as anticancer drugs. Mol Cancer Ther. 2004;3(4):513-9.

16. Zhang QY, Wang FX, Jia KK, Kong LD. Natural product interventions for chemotherapy and radiotherapy-induced side effects. Front Pharmacol. 2018;9:1253. doi: 10.3389/ fphar.2018.01253

17. Shabani A. A review of anticancer properties of herbal medicines. J Pharm Care Health Syst. 2016;3(2):2-5.

18. Greenwell M, Rahman PK. Medicinal plants: their use in anticancer treatment. Int J Pharm Sci Res. 2015;6(10):410312. doi: 10.13040/ijpsr.0975-8232.6(10).4103-12.

19. Eskandani M, Dadizadeh E, Hamishehkar H, Nazemiyeh $\mathrm{H}$, Barar J. Geno/cytotoxicty and apoptotic properties of phenolic compounds from the seeds of Dorema glabrum Fisch. C.A. Bioimpacts. 2014;4(4):191-8. doi: 10.15171/ bi.2014.019.

20. Yin SY, Wei WC, Jian FY, Yang NS. Therapeutic applications of herbal medicines for cancer patients. Evid Based Complement Alternat Med. 2013;2013:302426. doi: 10.1155/2013/302426.

21. Asnaashari S, Dadizadeh E, Talebpour AH, Eskandani $\mathrm{M}$, Nazemiyeh $\mathrm{H}$. Free radical scavenging potential and essential oil composition of the Dorema glabrum Fisch. C.A. mey roots from Iran. Bioimpacts. 2011;1(4):241-4. doi: 10.5681/bi.2011.035.

22. Masoudi S, Kakavand S. Volatile constituents of the aerial parts of Terataenium lasiopentalum (Boiss.) Manden., stems and leaves of Dorema ammoniacum D. Don. and leaves, fruits and stems of Leutea petiolare (DC.) M. Pimen from Iran. J Chil Chem Soc. 2017;62(1):3311-4. doi: 10.4067/ s0717-97072017000100001.

23. Akbarian A, Rahimmalek M, Sabzalian MR. Variation in essential oil yield and composition of Dorema aucheri Boiss., an endemic medicinal plant collected from wild populations in natural habitats. Chem Biodivers. 2016;13(12):1756-66. doi: 10.1002/cbdv.201600160.

24. Delnavazi MR, Hadjiakhoondi A, Delazar A, Ajani Y, Tavakoli S, Yassa N. Phytochemical and antioxidant investigation of the aerial parts of Dorema glabrum Fisch. \& C.A. Mey. Iran J Pharm Res. 2015;14(3):925-31.

25. Masoudi S, Esmaeili A, Ali khalilzadeh M, Rustaiyan A, Moazami N, Akhgar MR, et al. Volatile constituents of Dorema aucheri Boiss., Seseli libanotis (L.) WD Koch var. armeniacum Bordz. and Conium maculatum L. three Umbelliferae herbs growing wild in Iran. Flavour Fragr J. 2006;21(5):801-4.

26. Hosseini SAR, Naseri HR, Azarnivand $H$, Jafari $M$ Rowshan V, Panahian AR. Comparing stem and seed essential oil in Dorema ammoniacum D. Don. from Iran. J Essent Oil Bear Plants. 2014;17(6):1287-92. doi: 10.1080/0972060X.2014.977572.

27. Hajlaoui H, Trabelsi N, Noumi E, Snoussi M, Fallah H, Ksouri R, et al. Biological activities of the essential oils and methanol extract of tow cultivated mint species (Mentha longifolia and Mentha pulegium) used in the Tunisian folkloric medicine. World J Microbiol Biotechnol. 2009;25(12):2227-38. doi: 10.1007/s11274-009-0130-3.

28. Thoppil RJ, Bishayee A. Terpenoids as potential chemopreventive and therapeutic agents in liver cancer. World J Hepatol. 2011;3(9):228-49. doi: 10.4254/wjh. v3.i9.228.

29. Bannazadeh Amirkhiz M, Rashtchizadeh N, Nazemieh $\mathrm{H}$, Abdolalizadeh J, Mohammadnejad L, Baradaran B. Cytotoxic effects of alcoholic extract of dorema glabrum seed on cancerous cells viability. Adv Pharm Bull. 2013;3(2):403-8. doi: 10.5681/apb.2013.064

30. Yousefzadi M, Heidari M, Akbarpour M, Mirjalili MH, Zeinali A, Parsa M. In vitro cytotoxic activity of the essential oil of Dorema ammoniacum D. Don. Middle-East J Sci Res. 2011;7(4):511-4.

31. Sarwar MS, Zhang HJ, Tsang SW. Perspectives of plant natural products in inhibition of cancer invasion and metastasis by regulating multiple signaling pathways. Curr 
Med Chem. 2018;25(38):5057-87. doi: 10.2174/0929867324 666170918123413.

32. Yen GC, Tsai CM, Lu CC, Weng CJ. Recent progress in natural dietary non-phenolic bioactives on cancers metastasis. J Food Drug Anal. 2018;26(3):940-64. doi: 10.1016/j.jfda.2018.05.003.

33. Pan Z, Wang SK, Cheng XL, Tian XW, Wang J. Caryophyllene oxide exhibits anti-cancer effects in MG-63 human osteosarcoma cells via the inhibition of cell migration, generation of reactive oxygen species and induction of apoptosis. Bangladesh J Pharmacol. 2016;11(4):817-23. doi: 10.3329/bjp.v11i4.27517.

34. Jung JI, Kim EJ, Kwon GT, Jung YJ, Park T, Kim Y, et al. $\beta$-Caryophyllene potently inhibits solid tumor growth and lymph node metastasis of B16F10 melanoma cells in highfat diet-induced obese C57BL/6N mice. Carcinogenesis.
2015;36(9):1028-39. doi: 10.1093/carcin/bgv076.

35. Milawati $H$, Harneti D, Maharani R, Nurlelasari N, Hidayat AT, Azmi MN, et al. Caryophyllene-type sesquiterpenoids from the stembark of Aglalia harmsiana and their cytotoxic activity against MCF-7 breast cancer cells. Molekul. 2019;14(2):126-32. doi: 10.20884/1.jm.2019.14.2.543

36. Alencar M, Islam MT, Ali ES, Santos JVO, Paz M, Sousa JMC, et al. Association of phytol with toxic and cytotoxic activities in an antitumoral perspective: a meta-analysis and systemic review. Anticancer Agents Med Chem. 2018;18(13):1828-37. doi: 10.2174/1871520618666180821 113830 .

37. Islam MT, Ali ES, Uddin SJ, Shaw S, Islam MA, Ahmed MI, et al. Phytol: a review of biomedical activities. Food Chem Toxicol. 2018;121:82-94. doi: 10.1016/j.fct.2018.08.032. 